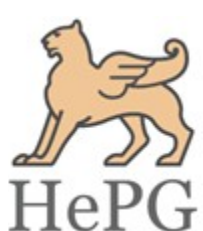

ISSN: 2348-1900

Plant Science Today

http://horizonepublishing.com/journals/index.php/PST

Research Article

\title{
Hornwort diversity at Pachmarhi Biosphere Reserve (Madhya Pradesh), India
}

\author{
Reesa Gupta and A. K. Asthana* \\ Bryology Laboratory, CSIR - National Botanical Research Institute, Lucknow-226 001
}

\section{Article history}

Received: 15 September 2015

Accepted: 18 September 2015

Published online: 1 October 2015

(c) Gupta and Asthana (2015)

Editors

Afroz Alam

Dipjyoti Chakraborty

Publisher

Horizon e-Publishing Group

Corresponding Author

A. K. Asthana

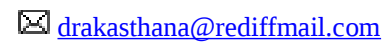

\begin{abstract}
Pachmarhi Biosphere Reserve (PBR) has been a major spot of biodiversity in central India, particularly in terms of cryptogamic flora. Hornworts are the group of bryophytes placed under Division Anthocerotophtya which form a significant assemblage with phylogenetic and evolutionary importance as these plants possess characteristics that relate to the vascular plants. As a result their taxonomic studies, diversity assessment and understanding of their affinities hold much importance. India harbours 39 hornwort taxa, out of which nine have been listed from PBR. Among these five taxa viz. Anthoceros bharadwajii Udar et Asthana, Phaeoceros carolinianus (Michx.) Prosk., P. kashyapii Asthana et Sriv., P. laevis (L.) Prosk. and P. udarii Asthana et Nath have been encountered from the study area. The total diversity of hornworts at PBR, including the previously listed taxa and those elucidated in the present study suggests that these plants contribute substantially towards the bryophyte diversity of the Biosphere Reserve.
\end{abstract}

\section{Keywords}

Anthocerotophyta; bryophytes; Pachmarhi Biosphere Reserve

Gupta, R and Asthana, A. K. 2015. Hornwort diversity at Pachmarhi Biosphere Reserve (Madhya Pradesh), India. Plant Science Today 2(4): 145-150. http://dx.doi.org/10.14719/pst.2015.2.4.149

\section{Introduction}

Pachmarhi Biosphere Reserve (PBR) has long been celebrated as the most biodiversity rich area of the central Indian bryo-geographical region, for the diversity of both cryptogams and angiosperms. The Biosphere Reserve covers an extensive area of 4987.38 sq. meters and encompasses three conservation units viz. Pachmarhi Sanctuary, Satpura National Park and Bori sanctuary. The Pachmarhi Sanctuary and areas surrounding it has been a tourist spot for a long time and perhaps the most widely accessed area of the Biosphere Reserve. The cryptogamic flora prevailing here has enticed the Indian bryologists time and again to unveil the bryoflora of the region. In such attempts bryologists have listed liverworts and hornworts of Pachmarhi for the first time nearly 60 years ago (Pande and Srivastava, 1952). The next four decades saw only a few accounts of one or two taxa from this region. Kaul (2001) and later Singh and Kaul (2002) subsequently provided consolidated accounts of the liverworts and hornworts of PBR region. Most recently Asthana and Nath (2007) listed current status of liverworts and hornworts while Sharma \& Alam (2011) listed current status of liverworts alone from the region.

The bryophyte flora of this region has been explored to considerable extent but liverworts have attracted more attention of the workers in the initial decades of explorations. The taxonomic investigations of hornworts and mosses were taken up later on by bryologists. Hornworts are the group of bryophytes placed under Division Anthocerotophyta characterised by thalloid plant body usually growing in rosettes with needle or horn like elongated sporophytes. This is a significant group of bryophytes which has phylogenetic and evolutionary importance as these plants possess characteristics that relate to the vascular plants. The members of this group 
Table 1. Distribution of the studied hornworts in geographical regions of India

\begin{tabular}{|c|c|c|c|c|c|}
\hline \multirow{2}{*}{ S. No. } & \multirow{2}{*}{ HORNWORTS } & \multicolumn{4}{|c|}{ BRYOGEOGRAPHICAL REGIONS OF INDIA } \\
\hline & & $\begin{array}{l}\text { WESTERN } \\
\text { HIMALAYA }\end{array}$ & $\begin{array}{l}\text { EASTERN } \\
\text { HIMALAYA }\end{array}$ & $\begin{array}{l}\text { CENTRAL } \\
\text { INDIA }\end{array}$ & $\begin{array}{c}\text { SOUTH } \\
\text { INDIA }\end{array}$ \\
\hline 1. & Anthoceros bharadwajii & + & + & + & + \\
\hline 2. & Phaeoceros carolinianus & + & + & + & + \\
\hline 3. & Phaeoceros laevis & + & + & + & + \\
\hline 4. & Phaeoceros kashyapii & + & - & + & - \\
\hline 5. & Phaeoceros udarii & + & - & + & - \\
\hline 6. & Anthoceos erectus* & + & - & + & + \\
\hline 7. & Folioceros satpurensis* & - & - & (C) & - \\
\hline 8. & Notothylas indica* & + & + & + & + \\
\hline 9. & Notothylas levieri* & + & + & + & - \\
\hline
\end{tabular}

exhibit the presence of pyrenoids, stoma on capsule wall, the presence of a photosynthetic (less parasitic) sporophyte, its indeterminate growth, and indeterminate reproductive capacity as the characteristics that we find in vascular plant sporophytes and makes their phylogenetic study worth investigating. Important contributions on hornworts in general by Villarel et al. (2010) and on Indian hornworts by Bharadwaj (1965, 1971, 1978); Udar and Asthana (1985, 1985a), Udar and Singh (1981, 1981a), Asthana and Srivastava (1991); Singh (2002); Asthana and Nath (1994, 2002, 2004) are worth mentioning here. However specific accounts of hornwort distribution in central India remain lacking.

India boasts of harbouring 39 hornwort taxa, out of which 9 have been listed from PBR. Among these, five taxa viz., Anthoceros bharadwajii Udar et Asthana, Phaeoceros carolinianus (Michx.) Prosk., P. kashyapii Asthana et Sriv., P. laevis (L.) Prosk. and P. udarii Asthana et Nath have been encountered and described in the present study. The other five taxa namely Anthoceos erectus Kash., Folioceros satpurensis (Sriv.) Bharad. \& Sriv., Notothylas indica Kash., Notothylas levieri St. ex Schiffn., and Phaeoceros communis (Steph.) Schiffn. et Pandé have been reported previously from this area. Among these the status of Phaeoceros communis (Steph.) Schiffn. et Pandé is unresolved.

\section{Materials and Methods}

The specimens were collected during 1992, 1993, 2006 and 2011 successively from 14 localities (Map I) of PBR covering an altitudinal range of 400 to 1056 meters. These were collected from soil, soil covered rocks and bare wet rocks. The collections have been deposited in the Herbarium, CSIR-National Botanical Research Institute, Lucknow (LWG), India.

\section{Taxonomic Observations}

\section{Anthoceros bharadwajii Udar et Asthana in Proc. Indian Natn. Sci. Acad. B 51 (4): 484, 1985.}

Plants thalloid, dioicous, dark green, fan shaped with lobes, up to $10 \mathrm{~mm}$ wide, spongy. Dorsal surface smooth, mucilage chambers seen along the margin. Male plants not seen. Involucre $\pm 3 \mathrm{~mm}$ long, mouth narrow; capsule wall has stomata, stoma $\pm 65 \mu \mathrm{m}$ long, up to $50 \mu \mathrm{m}$ wide, guard cells reniform; spores dark brown, 35- $45 \mu \mathrm{m}$ in size, spinulate projections forming pseudoreticulate- reticuloid pattern, proximal face has tri-radiate mark with unsculptured stripe; pseudoelaters light brown, up to $120 \mu \mathrm{m}$ long, 4 celled, rarely branched.

Ecology and Distribution: Plants growing luxuriantly on soil covered rocks under moist conditions at Tamia, $1000 \mathrm{~m}$.

Range of Distribution: India: eastern Himalaya (Darjeeling, Shillong peak, Elephant Fall, Mao, Ukhrul), central India (PBR, Amarkantak, Mt. Abu), South India (Kerala, Trichur, Munnar, Devicolam, Murukkady, Peermade, Periavurrai, Naduvattam, western Himalaya (Deoban, Nainital, Pauri).

Specimens examined: India, Madhya Pradesh, PBR: Tamia, alt. ca $1000 \mathrm{~m}, 10.10 .1992$. leg. V. Nath \& A.K. Asthana (LWG) 205488.

\section{Phaeoceros carolinianus (Michx.) Prosk. in Bull. Torrey Bot. Club. 78. 347: 1951.}

Plants thalloid, monoicous, dark green, deeply lobed, \pm 12 x10 mm in size, broader towards apex, narrower at base. Dorsal surface smooth, androecial chambers 


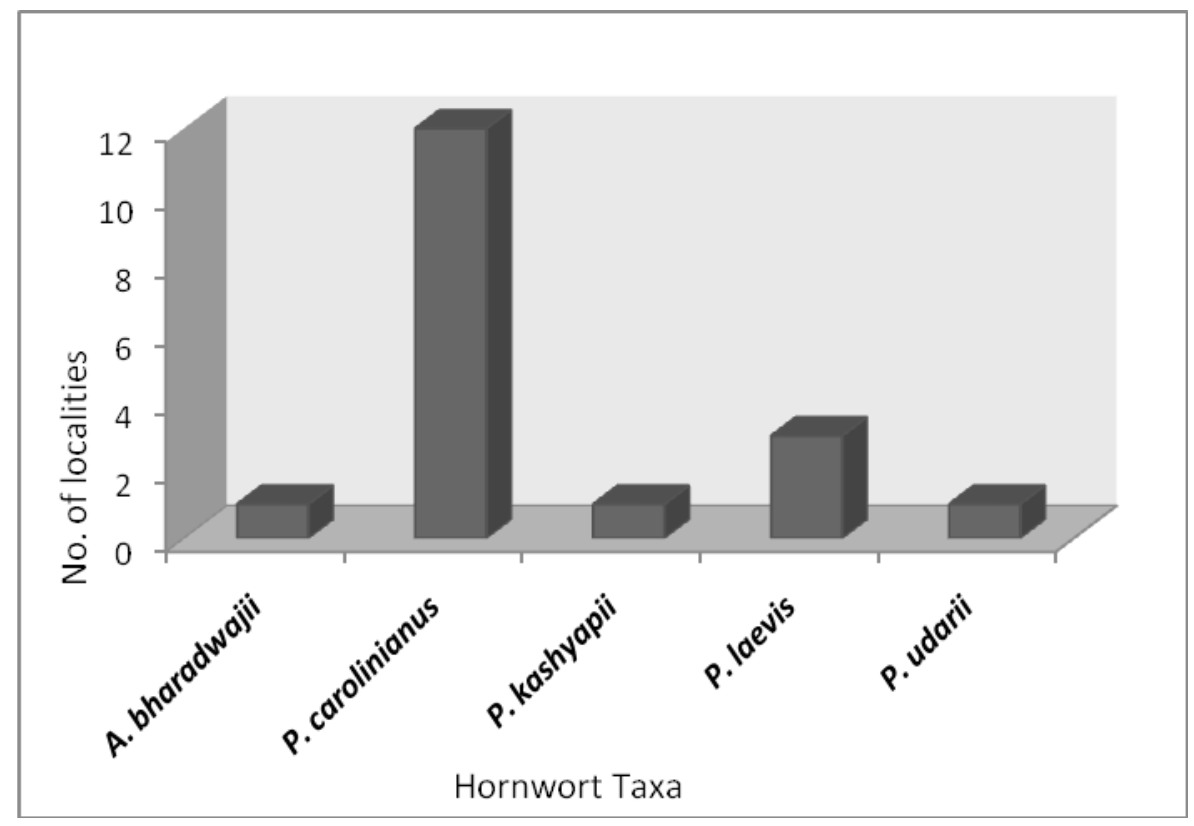

Fig 1. Distribution of hornworts at Pachmarhi Biosphere Reserve

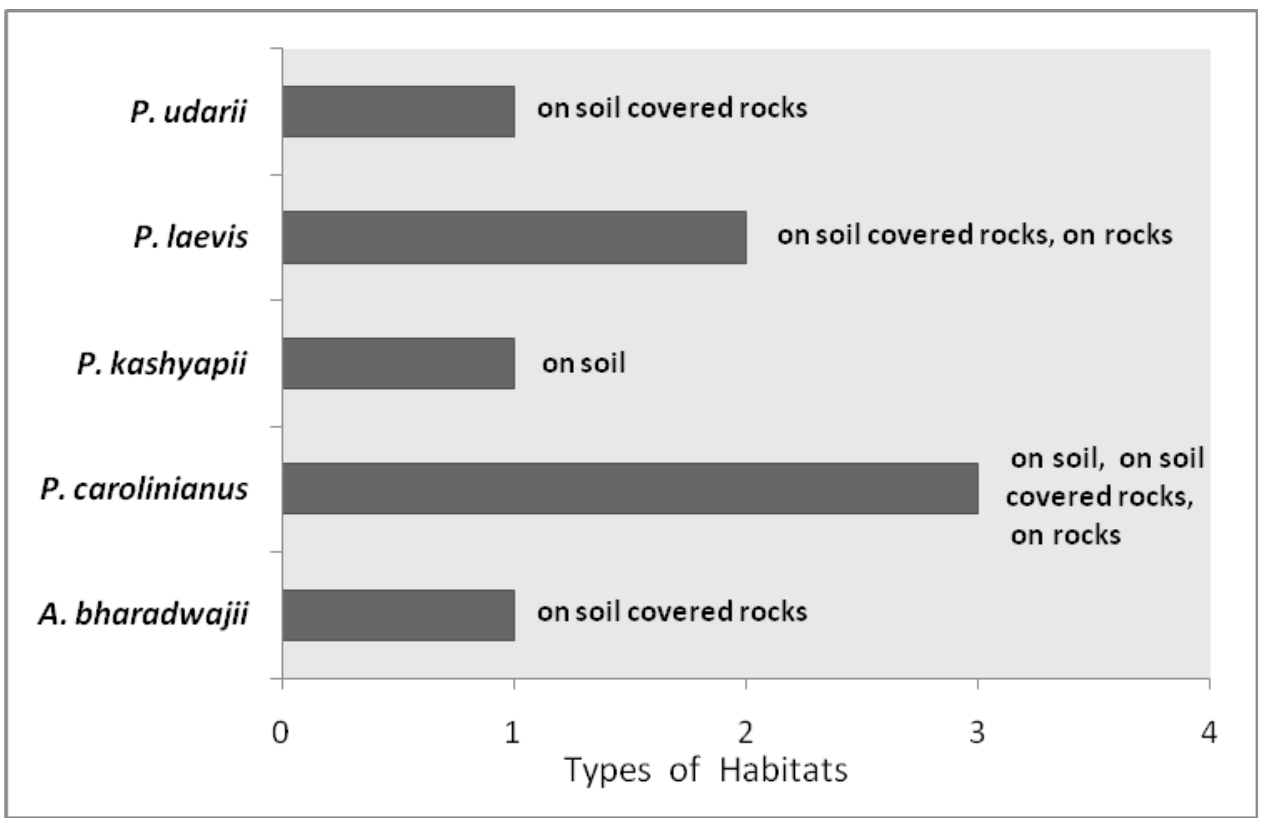

Fig 2. Habitat distribution of hornworts at Pachmarhi Biosphere Reserve

irregularly scattered; rhizoids present on ventral surface. Involucres cylindrical, 2- $4 \mathrm{~mm}$, compact, narrower at mouth; capsule wall has stomata, up to $80 \times 40 \mathrm{~mm}$ in size, two reniform guard cells; spores yellowish-dull green, $\pm 35 \mu \mathrm{m}$ in diameter, sporoderm papillate, triradiate mark on proximal face; pseudoelaters yellowish-brown, up to $150 \mu \mathrm{m}$ long, irregular thickening bands present.

Ecology and Distribution: Plants growing over soil covered rocks, over wet rocks and on soil in moist conditions at Chota Mahadev (Tamia), near new Hotel, Down Fall, Jambu Dweep, Mahadeo Caves, Rajakhoh (Patalkot), Mahadev Mandir, near Bee Fall, Apsara Fall and Bee Dam area from 400-1056 m.

Range of Distribution: Antarctica, Australia, Belize, Bhutan, Brazil, Costa Rica, Czech Republic, Denmark,
Europe, French Polynesia, India: [central India (PBR, Amarkantak- Achanakmar, Mt. Abu), eastern Himalaya (Darjeeling, Teesta Valley, Ray Villi Road, Gangtok, Manipur, Sikkim), South India (Kodaikanal), western Himalaya (Baijnath Putlikuhl, Kausani, Mussoorie, Nagar Road)], Indonesia, Italy, Japan, Nepal, Jamaica, Japan, Mexico, Netherland, New Caledonia, New Zealand, Norway, Papua New Guinea, Portugal, Puento Rico, Romania, Russia Spain, Sri Lanka, Sweden, Switzerland, Thailand, United Kingdom.

Specimens examined: India, Madhya Pradesh, PBR: Tamia Valley, alt. ca $1000 \mathrm{~m}$, on soil, 10.10.1992, 205503 (LWG); Chota Mahadev (Tamia) alt. ca 953 m, on soil, 11.10.1992, 205524 (LWG); near New Hotel (FRH Road), alt. ca $1056 \mathrm{~m}$, on soil (at sides of Nallah) 15.12.1993, 205531, 205536; 205538 (LWG); Down Fall, 


\section{MAP-I: COLLECTION SITES OF HORNWORTS AT PACHMARHI BIOSPHERE RESERVE}

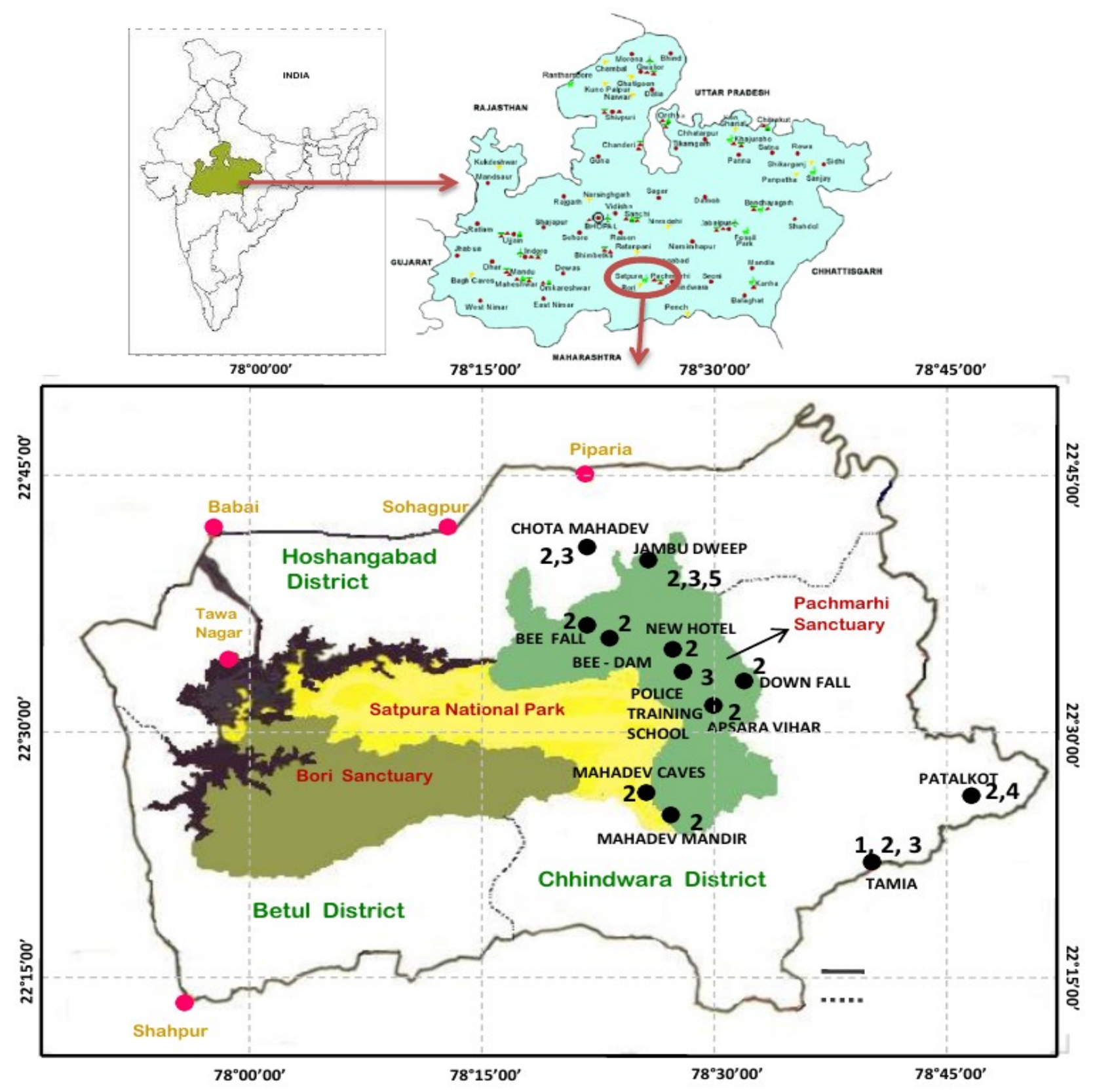

alt. ca $1056 \mathrm{~m}$, on moist rocks, 15.12.1993, 205550, 205553 (LWG); Jambu Dweep alt. ca 900 m, on soil over rocks, 17.12.1993, 205623A (LWG); Mahadeo Caves, alt. ca $1000 \mathrm{~m}$, on extremely wet rocks, 17.12.1993, 205635, 205638B, 205640, 205643 (LWG); Chota Mahadev (Tamia), alt. ca $950 \mathrm{~m}$, on soil covered rocks, 19.12.1993, 205708 (LWG); Rajakhoh (Patalkot), alt. ca $400 \mathrm{~m}$, on rocks, 20.12.1993, 205727, 205730 (LWG). leg. V. Nath \& A.K. Asthana; Down Fall, alt. ca $884 \mathrm{~m}$, on rocks, 28.11.2006, 227605A (LWG); Mahadev Mandir, alt. ca $1006 \mathrm{~m}$, on wet rocks, 28.11.2006, 227609 (LWG); on way to Mahadev Mandir, alt. ca $1006 \mathrm{~m}$, on rocks, 28.11.2006, 227615A (LWG); on way to Chota Mahadev, alt. ca $793 \mathrm{~m}$, on rocks, 29.11.2006, 227634 (LWG); on way to Bee Fall, alt. ca $823 \mathrm{~m}$, on wet rocks, 30.11.2006, 227666A
(LWG); Apsara Fall, alt. ca $734 \mathrm{~m}$, on moist rocks, 01.12.2006, 227700 (LWG), leg. V. Sahu \& V. Awasthi; Bee Dam, alt. ca $976 \mathrm{~m}$, on wet soil, 08.11.2011, 263192 (LWG); Bada Mahadev, alt. ca 1075 m, on soil covered rocks, 08.11.2011, 264816 (LWG). leg. A.K. Asthana \& R. Gupta.

\section{Phaeoceros laevis (L.) Prosk. in Bull. Torrey Bot.} Club 78: 347, 1951.

Plants thalloid, dioicous, light to dark green, branched, up to 11 x $10 \mathrm{~mm}$ in size, deeply lobed, wider at apex, margin entire, wavy. Male plants not seen. Involucre cup shaped, cylindrical, 2-6 mm long, mouth wide; smooth; capsule wall with stomata, 5075 x $40 \mu \mathrm{m}$ in size with two reniform guard cells; 
spores yellowish green, spherical, $\pm 45 \mu \mathrm{m}$ in diameter, sporoderm papillate, distinct tri-radiate mark on proximal surface; pseudoelaters light brown, 4 celled, up to $168 \mu \mathrm{m}$ long.

Ecology and Distribution: Plants growing on bare rocks near water stream and on soil covered rocks at Chota Mahadev (Tamia), near Police Training School and Jambu Dweep from 900-1000 m.

Range of Distribution: Antarctica, Antilles, Australia, Belgium, Bonin, Brazil, Bulgaria, Canada, China, Coimbra, Cyprus, Czech Republic, Ecuador, France, Germany, Greece, Guatemala, Honduras, Iceland, India: [eastern Himalaya (Ukhrul, Mongpo, Nathula road, Manipur, Sikkim) central India (AABR, PBR), South India (Mahabaleshwar, Ooty, Mukurty, Kodaikanal, Shembaganur, Devicolam, Vagavurrai, Mysore), western Himalaya (Company Garden, Mussoorie, Pauri, Simla)], Iran, Ireland, Israel, Italy, Japan, Lebanon, Liukiu, Madrid, Malta, Mauritius, Mexico, Moldova, Morocco, Nicaragua, N. America, Nepal, Pakistan, Papua New Guinea, Peru, Philippines, Pompeii, Poland, Portugal, Reunion, Romania, Russia, South Africa, Spain, Sri Lanka, Sweden, Switzerland, Taiwan, Turkey, Ukraine, United Kingdom, United States, Venezuela, Yemen.

Specimens examined: India, Madhya Pradesh, PBR: Jambu Dweep, alt. ca $1000 \mathrm{~m}$, on rocks (near water stream), 17.12.1993, 205624B (LWG); Tamia, Chota Mahadev, ca $950 \mathrm{~m}$, on rocks (near water stream) 19.12.1993, 205687 (LWG). leg. V. Nath \& A.K. Asthana; near Police Training School, alt. ca $914 \mathrm{~m}$, on soil covered rocks, 28.11.2006, 229381A (LWG). leg V. Sahu \& V. Awasthi.

\section{Phaeoceros kashyapii Asthana et Sriv.} Bryophyt. Biblioth. Band 42: 129, 1991.

Plants thalloid, monoicous, light green, lobed, $\pm 10 \mathrm{x}$ 4-6 $\mathrm{mm}$ in size, broader above, narrower at base, compact. Male receptacles not seen. Involucre cylindrical, smooth, $\pm 3 \mathrm{~mm}$ long; capsule wall stomatiferous, each stoma with 2 reniform guard cells. Spores yellowish green, 37-40 $\mu \mathrm{m}$ in diameter, sporoderm with lamellate projections, prominent triradiate mark on proximal face; pseudoelaters pale to light brown, smooth, 70-100 $\mu \mathrm{m}$ long.

Ecology and Distribution: Plants growing on soil covered rocks under moist conditions on way to Rajakhoh at $400 \mathrm{~m}$.

Range of Distribution: India: central India (PBR), western Himalaya (Deoban, Vyas Shikhar).

Specimens examined: India, Madhya Pradesh, PBR: Patalkot, on way to Rajakhoh, alt. ca 400m, 06.10.1992. 205475 (LWG) leg. V. Nath \& A.K. Asthana.

\section{Phaeoceros udarii Asthana et Nath in Proc. Nat. Acad. Sci. India 63 (B) IV: 461-464. 1993.}

Plants thalloid, dull green in patches, broader above, narrow at base, broader above, compact. Male receptacles not seen. Involucre smooth, $\pm 3.2 \mathrm{~mm}$. Capsule long, wall 5-6 layers thick, stomatiferous, stoma guarded by 2 reniform guard cells. Spores light green $\pm 37 \mu \mathrm{m}$ in size, sporoderm minutely papillate; prominent tri-radiate mark on proximal face; pseudoelaters dull brownish with minute papillae on the surface, 90-120 $\mu \mathrm{m}$ long.

Ecology and Distribution: plants growing on soil over rock at Jambu Dweep, $900 \mathrm{~m}$.

Range of Distribution: India: central India (PBR), western Himalaya (Mussoorie).

Specimens examined: India, Madhya Pradesh, PBR: Jambu Dweep, alt. ca $900 \mathrm{~m}$, on soil over rock, 17.12.1993, 205606 (LWG). leg. V. Nath \& A.K. Asthana.

\section{Results and Discussion}

Among the five species of hornworts encountered from PBR, $P$. carolinianus is remarkably dominant and widespread in the area, both in terms of occurrence and altitudinal variation, being present in 12 localities of collection, ranging from 400-1056 meters. $P$. laevis is present at three localities from 900-1000 meters, while A. bharadwajii, P. kashyapii and $P$. udarii each have been encountered at single locality of PBR, at 1000, 400 and 900 meters respectively. The hornworts have been found at terrestrial habitats such as on soil, on soil covered rocks and on bare wet rocks. Among the five taxa, $P$. carolinianus is present on all the three habitats while $P$. laevis is found harbouring two habitats viz. on soil covered rocks and bare rocks. $P$. kashyapii is found growing only on soil whereas both $A$. bharadwajii, and $P$. udarii are found only on soil covered rocks (Fig $1,2)$.

The overall scenario of the hornwort distribution strongly suggests that $P$. carolinianus is the most successful and dominant taxon at the study area. The total diversity of hornworts at PBR, including the previously listed taxa and those elucidated in the present study suggests that these plants contribute substantially towards the bryophyte diversity of the Biosphere Reserve.

In the Indian scenario, the most widely distributed hornworts known from PBR are A. bharadwajii, $P$. carolinianus, $P$. laevis and $N$. indica being distributed at all the four geographical regions. Folioceros satpurensis is endemic to PBR, whereas $P$. kashyapii and $P$. udarii show distribution in central India and western Himalaya only (Table 1).

\section{Acknowledgements}

The authors are grateful to the Director, CSIRNational Botanical Research Institute, Lucknow for encouragement and providing the laboratory facilities. One of the authors (RG) is grateful to CSIR, New Delhi, for providing Senior Research Fellowship.

\section{References}

Asthana, A. K. and Nath, V. 1994. Distributional pattern of genus Phaeoceros Prosk. in Kumaon and Garhwal region: Western Himalayas. Cryptogamie Bryol L 15 (2): 129-134.

Asthana, A. K. and Nath, V. 2002. SEM study on the sporoderm pattern of Folioceros assamicus Bharad. J Bryol 24 (4): 318-321. 
Asthana, A. K. and Nath, V. 2004. Studies on a rare Indian hornwort: Anthoceros alpinus Steph. J Bryol 26 (4): 303-305.

Asthana, A. K. and Nath, V. 2007. Hepatics and Anthocerotes (Bryophyta) of Tamia and Patalkot Valley (District Chhindwara), Madhya Pradesh. J Bombay Nat Hist Soc 104: 275-287.

Asthana, A. K. and Srivastava, S. C. 1991. Indian hornworts (a taxonomic study) Bryophyt Bibl 42: 1-230.

Bharadwaj, D. C. 1965. Studies in Indian Anthocerotaceae: VI. Some aspects of morphology of Phaeoceros Prosk. Phytomorphol 15: 140-150.

Bharadwaj, D .C. 1971. On Folioceros, a new genus of Anthocerotales. Geophytology 1(1): 6-15.

Bharadwaj, D. C. 1978. Studies in Indian Anthocerotaceae (V). Morpho-taxonomy of some Indian species of Folioceros Bharadwaj. Geophytology 8(1): 111-119.

Kaul, A. 2001. An Assessment of the Present Position of Hepatic Flora of Pachmarhi. In: V. Nath \& A.K. Asthana (eds.) Perspectives in Indian Bryology. Bishen Singh Mahendra Pal Singh, Dehra Dun, India. 75-86 pp.

Pande, S.K. and Srivastava, K.P. 1952. The hepatic vegetation of Pachmarhi (M.P.): A preliminary survey. J Indian Bot Soc 31: 342-351.

Sharma, D. and Alam, A. 2011. Present status of liverwort diversity at Pachmarhi (Madhya Pradesh). J Indian Bot Soc 90(3\&4): 332-338.

Singh D. K. 2002. Notothylaceae of India and Nepal. Bishen singh Mahendra Pal Singh. Dehradun. pp. 1-271.

Singh V.P. and Kaul, A. 2002 Biodiversity and Vegetation of Pachmarhi Hills. Scientific Publishers. Jodhpur, India. pp. $26-31$.

Udar, R. and Asthana A. K. 1985. Anthoceros bharadwajii, a new species from India. Proc Nat Acad Sci India 51 (4): 483-488.

Udar, R. and Asthana A. K. 1985a. A new Anthoceros from Nagaland. J Indian Bot Soc 64: 303-305.

Udar, R. and Singh, D. K. 1981. Some new conbinations under Phaeoceros Proskauer. Geophytology 11(2): 257-258.

Udar, R. and Singh, D. K. 1981a. Recent concept in the taxonomy of Notothylas. In: Contemporary Trends in Plant Sciences: Verma, S.C. Ed. Kalyani Pyublishers, New Delhi. pp. 162-174.

Villarel, J. C., Cargill, D.C., Hagborg, A. Soderstrom, L. and Renzaglia, K. 2010. A synthesis of hornwort diversity: Patterns, causes and future work. Phytotaxa 9: 150-166. 